\title{
Identification of the lower limit of high-quality source rocks and its relation to hydrocarbon accumulation- Taking the Beier Sag in the Hailaer Basin as an example
}

\author{
Lu Shuangfang1, 2*, Chen Fangwen ${ }^{1}$, Li Jijun", ${ }^{1,}$ Wang Weiming, ${ }^{1,2}$ \\ Li Huiguang ${ }^{1}$, Cao Ruicheng ${ }^{3}$ and Ma Yanling ${ }^{1}$ \\ ${ }^{1}$ College of Geosciences, Northeast Petroleum University, Heilongjiang 163318, China \\ ${ }^{2}$ Province Key Laboratory of Petroleum Accumulation Mechanism and Resource Prediction, Heilongjiang 163318, China \\ ${ }^{3}$ The Halaer Exploratory Development Headquarters, Daqing Oilfield Company Ltd., Heilongiiang 163000, China
}

(C) China University of Petroleum (Beijing) and Springer-Verlag Berlin Heidelberg 2012

\begin{abstract}
The theory of "source rock control" has evolved from source-rock-control hydrocarbon accumulation, to effective source-rock-control hydrocarbon accumulation, and to high-quality sourcerock-control hydrocarbon accumulation. However, there are problems, such as whether high-quality source rocks exist or not? What high-quality source rocks are, and how to identify them, are yet to be agreed upon. Aimed at this issue of concern to explorationists, and taking the Beier Sag in the Hailaer Basin as an example, this paper defines the high-quality source rocks and the lower limit for evaluation of high-quality source rocks, by using the inflection point on the relationship curve of hydrocarbon (oil) expulsion, which is calculated by the material balance principle, versus total organic carbon (TOC). The results show that when TOC is low, all source rocks have limited hydrocarbon expulsion and slow growth rate, thus they cannot be high-quality source rocks. However, when TOC rises to some threshold, hydrocarbon expulsion increases significantly with TOC. This inflection point should be the lower limit of high-quality source rocks: those with TOC greater than the inflection-point value are high-quality source rocks. In addition, the lower limit of high-quality source rocks is also related to the type and maturity of organic matters in the source rocks, as well as the mineral components of the source rocks affecting the residual hydrocarbons. Theoretically, the lower limit of high-quality source rocks depends on geological conditions rather than being a constant value. However, for the sake of simplicity and practicability, in this paper $\mathrm{TOC}=2.0 \%$ is regarded as the lower limit of high-quality source rocks. The examination of such standard in the work area indicates that the high-quality source rocks in members $K_{1} n^{2}$ and $K_{1} n^{1}$ of the Nantun formation contribute $76 \%$ and $82 \%$ to oil generation, and $96 \%$ and $91 \%$ to oil expulsion , respectively. The distribution of high-quality source rocks is also closely related to the distribution of hydrocarbon reservoirs in the region, demonstrating that high-quality source rocks control hydrocarbon accumulation.
\end{abstract}

Key words: High-quality source rocks, material balance, oil generation, oil expulsion, hydrocarbon generation potential, Beier Sag

\section{Introduction}

Hydrocarbon (HC) generation is a prerequisite for hydrocarbon migration and accumulation. So the theory

This research is funded by the 973 Prophase Special Program of China (NO.2011CB211701), National Natural Science Foundation of China (41172134), and CNPC Innovation Foundation (2011D-5006-0101).

*Corresponding author. email: lushuangfang@qq.com

Received May 28, 2011 of "source rock control" provides important guidance for improving the success rate of prospecting wells in hydrocarbon exploration. However, the content of "source rock control" theory does not remain unchanged. Instead, it has experienced development and evolution: In the early days, it is generally regarded as "source-rock-control hydrocarbon accumulation". For instance, the key exploration principle of "delimiting a depression and its boundaries" used in prospecting China's continental basins in the early days is a specific demonstration of such thought; Later on, it was gradually recognized that it is "effective source rocks" that 
control hydrocarbon accumulation and distribution of oil and gas pools. "Effective source rocks" refer to those source rocks that have generated and expelled commercial hydrocarbons. Generally, they are mature source rocks with good kerogen type and high total organic carbon (TOC) (Tissot and welte, 1978; Pang et al, 1995; Jin et al, 2000; Jin, 2001; Zhang et al, 2001). Nevertheless, with improving exploration practices and study, more and more geologists and geochemists tend to think that the major contributors to the commercial pools may be those mature high-quality source rocks which are not necessarily thick but have very high TOC (generally of good types), rather than those widely-distributed thick source rocks with low TOC. This is the thought of "high-quality source rock-control hydrocarbon accumulation" (Zhang et al, 2003; Zhu et al, 2004; Hou et al, 2008; Jin et al, 2008; Wang et al, 2009b; Pang et al, 2009; Qin et al, 2007; 2009; Tenger et al, 2006; Liu et al, 2009; He et al, 2010). Zhang et al (2003) believe that all of the giant fields with reserves of 100 million tonnes or above in the Jiyang Depression are closely related to high-quality source rocks. The theory of "high-quality source-rock-control hydrocarbon accumulation" has realistic significance especially in the complex continental faulted basins where lithology and lithofacies vary considerably and hydrocarbon migrates over short distances. Research by many scholars shows that high-quality source rocks have an important control effect on hydrocarbon accumulation, particularly for the lithologic reservoirs in the Jiyang Depression and Dongpu Sag (Hou et al, 2008; He et al, 2010).

By now, a lot of research on high-quality source rocks has been undertaken in the geochemistry field, especially by Chinese scholars. The research contents include the paleo-climate, paleo-sedimentary settings, petrological, geochemical, biomarker and maceral characteristics, spacetime distribution and dominant controlling factors related to high-quality source rock development, the relationship between high-quality source rocks and volcanic activity, upcurrents and hydrocarbon accumulation, and the identification and prediction of high-quality source rocks (Chen et al, 2006; Pedersen and Calvert, 1990; Moldowan et al, 1985; Liu et al, 2001; Li et al, 2008; Kong et al, 2000; Li and Xiao, 1988; Zhu and Jin, 2002; Li et al, 1986; Wang, 1990; Fu et al, 1991; Tang, 1986). However, agreement has not yet been reached on a standard of identifying highquality source rocks, which is of more concern to field explorationists. For instance, Zhou (2009) regards the mudstones with $\mathrm{TOC}>2 \%$ as high-quality source rocks through analysis of the data of the East China Sea and the Pearl River Mouth Basins; Zheng et al (2007) also take $\mathrm{TOC}=2 \%$ as the standard for identifying high-quality source rocks when they investigate the source rocks in the Nanpu Sag; Qin et al (2009) use the standard of TOC $\geq 2 \%$ when they study the high-quality source rocks of marine facies, but Qin thinks that for high-quality source rocks with type I kerogen, the lower limit of residual TOC can be about $1.5 \%$; Hou et al (2008) adopt TOC $>3 \%$ as the criterion for identifying highquality source rocks, based on analyzing the source rocks in the Jiyang Depression. They further classifies the high-quality source rocks with higher TOC (TOC $>6 \%$ ) as better source rocks enriched with more organic matter; Wang et al (2009b) see source rocks with good kerogen type and TOC $>1.0 \%$ as high-quality source rocks contributing greatly to hydrocarbon accumulation when they studied the Tertiary source rocks of salt lake facies in West Qaidam; Liu et al (2009) set TOC $>5.0 \%$ as the standard for identifying high-quality source rocks when studying the source rocks in the Hailaer Basin. In contrast, foreign scholars regard source rocks with TOC $>2 \%$ as high quality, and source rocks with TOC $>4 \%$ as very high quality (Hou et al, 2008).

More importantly, the criteria for evaluation of highquality source rock, given by the above scholars, are mainly empirical, without a theoretical basis and without convincing evidence. Aimed at this problem, and takes the Beier Sag in the Hailaer Basin as an example, this paper investigates the standard for evaluation of high-quality source rocks and the relationship between high-quality source rocks and hydrocarbon accumulation.

\section{Geologic overview of the Hailaer Basin}

The Hailaer Basin is located in the southwest of the Hulunbeier League, Inner Mongolia. It is the most important replacement area for the Daqing prospect area. The Beier Sag is one of the two key oil-bearing sags in the central fault belt of the Hailaer Basin, and also the major target of hydrocarbon exploration in the basin.

The basin base is mainly composed of Pre-Paleozoic and Paleozoic series. The sedimentary caprock consists of the Lower Cretaceous Tamulangou, Tongbomiao, Nantun, Damoguaihe and Yimin formations, the Upper Cretaceous Qingyuangang formation and Tertiary and Quaternary series of Cenozoic (Fig. 1). Among them, the possible source rocks, namely, the dark mudstones, coal mudstones and coal beds enriched in organic matters are primarily located in deep lake, semi-deep lake and marsh facies belts of the Nantun, Damoguaihe and Yimin formations. Most parts of the shallow-buried Damoguaihe and Yimin formations have not reached the maturity threshold, thus are unlikely to be effective source rocks in the region. In addition, explorationists normally divide the Nan-1 Member of Nantun formation $\left(\mathrm{K}_{1} \mathrm{n}^{1}\right)$ into the complex lithologic interval and the special lithologic interval according to their different sedimentary characteristics and logging curve characteristics, and these two intervals are generally evaluated separately. Taking this into consideration, the evaluation criteria of highquality source rocks are discussed separately targeting the two members $\left(K_{1} n^{1}\right.$ and $\left.K_{1} n^{2}\right)$ of the Nantun formation as well as the complex and special lithologic sections.

Complex cycle section: it is characterized by complex depositional cycles (reversed cycles) with alternating sandstones and mudstones. The lithologic section is generally 50-250 m thick, composed of 2-3 complex sedimentary cycles. Moderate acid alternating sandstones and mudstones enriched with sand dominate the section. On the seismic profile, there are sub-parallel to parallel reflections, and a large scale regional truncated surface dominates the top. In terms of logging curves, acoustic and density curves increase significantly, high GR, high resistivity, low uranium and high potassium responses are observed, and the logging curves 


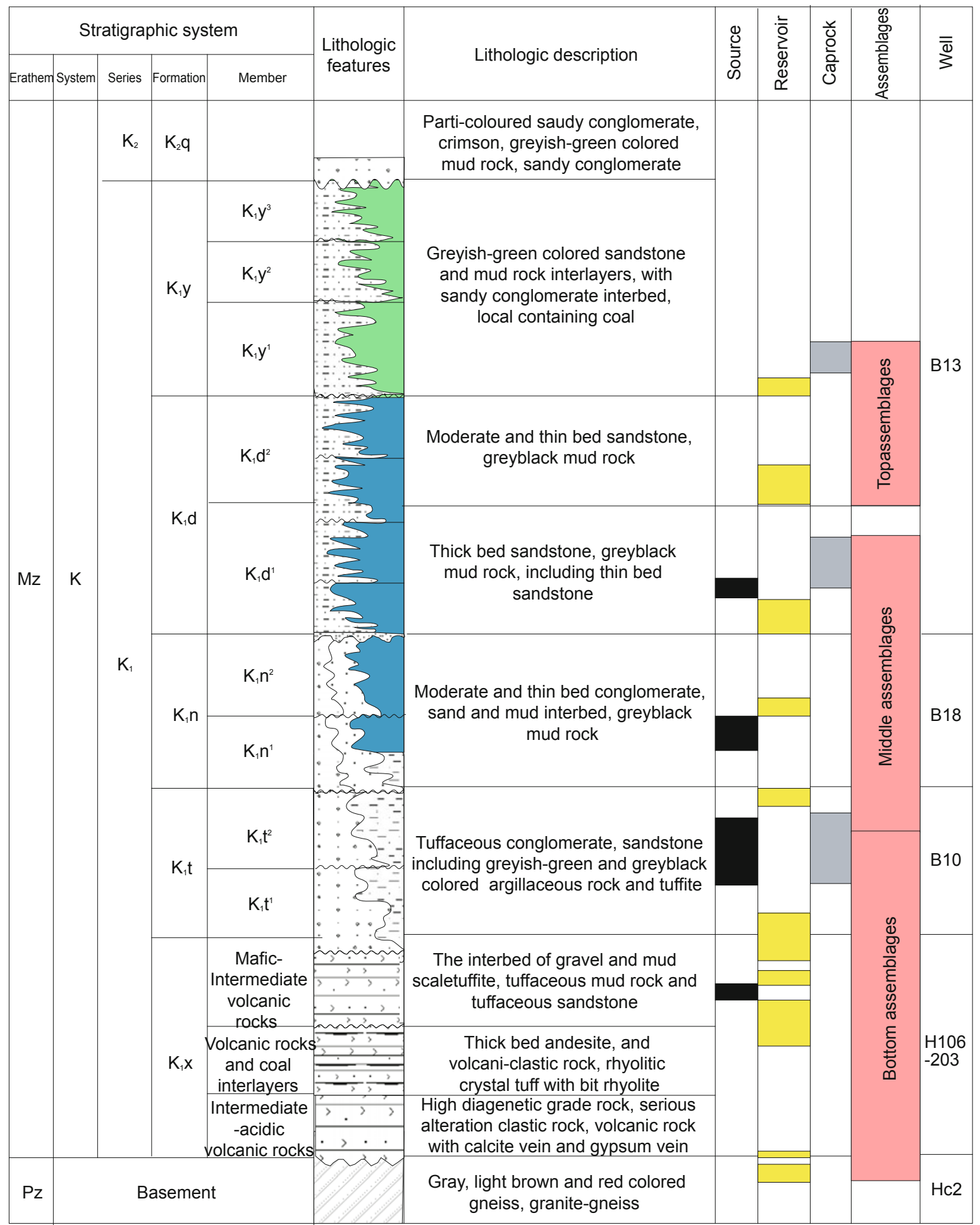

Fig. 1 Stratigraphic column of the Beier Sag

have even zigzag features.

Special lithologic section: it is a sandstone-mudstone alternating interval deposited in an environment where the water body was stable when the whole region subsided slowly under the background of gentle paleo-landforms. This is also reflected by passive rifting sedimentary features. The lithologic section is generally 40-100 m thick, with high-resistivity mudstones, oil shale and muddy limestones developed in aggradation. The logging curves are characterized by high GR, high resistivity, low uranium and high potassium responses.

\section{Identification of the lower limit of high- quality source rocks}

\subsection{Research thought-Are there high-quality source rocks present? What are high-quality source rocks?}

Since only those source rocks which have generated and expelled hydrocarbon can make material contributions to hydrocarbon accumulation, it is easy to understand that 
"effective source-rock-control hydrocarbon accumulation" can reflect the control of hydrocarbon accumulation by source rocks more objectively than "source-rock-control hydrocarbon accumulation", thus effective source-rockcontrol hydrocarbon accumulation is more valuable in guiding oil and gas exploration. However, "high-quality source-rock-control hydrocarbon accumulation" is a subject yet to be proved. Although "high-quality source rocks" can generate and expel more hydrocarbon thanks to their higher TOC and better kerogen type compared to equivalent volume of effective source rocks, whether or not "high-quality source rocks" contribute more to hydrocarbon accumulation depends on their relative scale to effective source rocks, considering the development and distribution scales of "high-quality source rocks" are often smaller than that of "effective source rocks" with a little lower TOC. For instance, the study of the Raoyang Sag in the Bohai Bay Basin undertaken by Wang et al (2009a) shows that the oil generated by high-quality source rocks accounts for $25 \%$ of the total oil in the sag, even though the thickness and volume of the high-quality source rocks is only $10 \%$ that of the gross source rocks in the sag. This indicates the high-quality source rocks contribute far less than a half to the hydrocarbon accumulation in the Renqiu paleo-buried hill reservoirs. If this is truly the case, it is not convincing to say that high-quality source rocks control hydrocarbon accumulation. Instead, they control hydrocarbon accumulation together with effective source rocks.

If there is a linear relationship between hydrocarbon expulsion of source rocks and their TOC (as the dashed line shown in Fig. 2), then, the concept of "high-quality source rocks" is not very important at least theoretically. The reason is that the reduction in TOC (meaning the hydrocarbon expulsion reduces proportionally) can be compensated by increasing equivalent volume of source rocks. Under normal geologic settings, the source rocks with lower TOC are generally developed in larger scale, which can compensate the lower TOC in per unit mass. However, if the relationship between hydrocarbon expulsion of source rocks and their TOC is the solid line as shown in Fig. 2, or there is a clear inflection point on the hydrocarbon expulsion versus TOC curve, it is necessary to present the concept of "high-quality source rocks" and highlight its importance: above the inflection point, the growth rate of hydrocarbon expulsion with TOC is significantly higher than that below the inflection point. In other words, when having the same absolute TOC, the source rocks above the inflection point expel much more hydrocarbon than those below the inflection point. The source rocks above the inflection point are the high-quality source rocks, and this inflection point is the lower limit of highquality source rocks. If there is a second inflection point on the curve when the growth rate of hydrocarbon expulsion accelerates as TOC rises, it is necessary to classify a group of better source rocks among the high-quality source rocks.

Therefore, as long as the hydrocarbon expulsion versus TOC curve can be obtained, one can determine whether high-quality source rocks exist or not, then determine the evaluation standard of high-quality source rocks. Among the available methods for evaluating the hydrocarbon expulsion of source rocks, the material balance theory, namely the

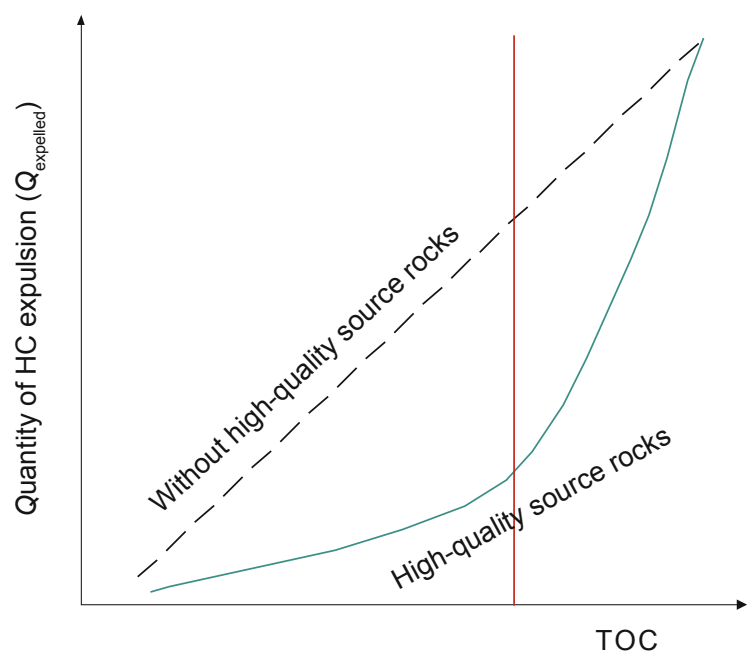

Fig. 2 Concept of high-quality source rocks and the evaluation standard

quantity of hydrocarbons expelled is equal to the quantity of hydrocarbon generated minus the quantity of hydrocarbon residual $\left(Q_{\text {expelled }}=Q_{\text {generated }}-Q_{\text {residual }}\right)$, is of wide validity and feasibility (Pang, 1995; Lu et al, 2002). In view of this, the material balance method is used to discuss the concept of "high-quality source rocks" and their evaluation criteria in this paper by taking the Beier Sag as an example.

3.2 Calculation of hydrocarbon generation (i.e. quantity of hydrocarbon generated, $Q_{\text {generated }}$ ) per unit mass source rocks

$$
Q_{\text {generated }}=\mathrm{TOC}^{0} \times \mathrm{IH}^{0} \times X
$$

where, $\mathrm{TOC}^{0}$ is the original total organic carbon in the source rocks (\%), $\mathrm{IH}^{0}$ is the original hydrocarbon generation potential in unit mass of TOC (mg-HC/g-TOC or kg-HC/ t-TOC, which reflects the type of kerogen), and $X$ is the rate of hydrocarbon generation (\%). $X$ can be calculated by using chemical kinetics, and the details can be found in the previous paper ( $\mathrm{Lu}, 1$ 1996; Lu et al, 2007; 2009) for its theory, procedures and calculation results. The original organic carbon and original hydrocarbon generation potential are calculated with the residual organic carbon and hydrogen index, respectively, based on chemical kinetics, of which the principle and application are reported in the previous paper (Lu et al, 1995). Fig. 3 shows the relationship between the $\mathrm{IH}^{0}$ and $\mathrm{TOC}^{0}$ of the $\mathrm{K}_{1} \mathrm{n}^{1}$ source rocks in the Beier Sag. The amount of generated hydrocarbon corresponding to different TOC levels is easy to calculate using Eq. (1) based on the data shown in Fig. 3.

\section{3 Calculation of residual hydrocarbon (oil) $\left(Q_{\text {residual }}\right)$ of unit mass of source rocks}

The measured chloroform asphalt "A" in source rocks can be seen as the residual oil in unit mass of source rocks. The only thing needed to do is to convert its unit so that the measured chloroform asphalt " $A$ " and the oil generation is in the same unit ( $\mathrm{kg} / \mathrm{t}$ source rocks). Due to the heterogeneity of source rocks, the amount of chloroform asphalt "A" of the same source rock layer at the same burial depth with the 


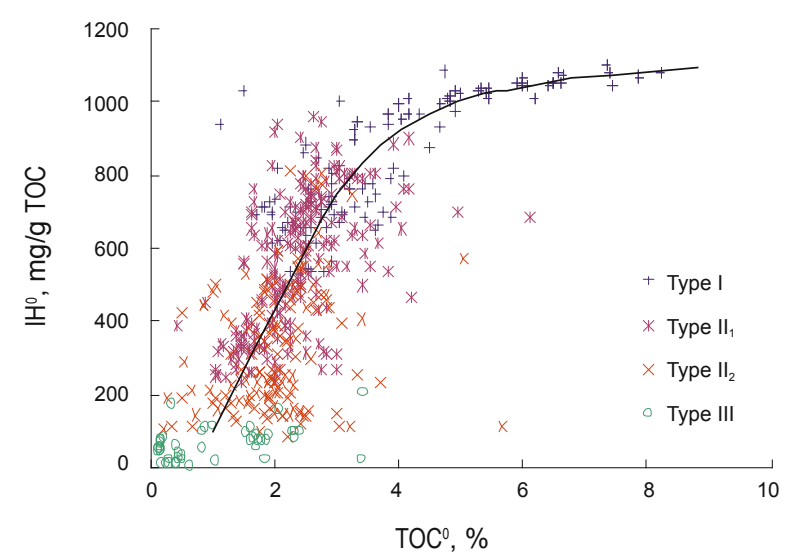

Fig. 3 Relationship between TOC and hydrocarbon generation potential of the $\mathrm{K}_{1} \mathrm{n}^{1}$ source rocks in the Beier Sag

same TOC may differ greatly in different horizontal positions. Therefore, the half amplitude value (or the average value at a specific depth interval or within a specific range of TOC) of the envelope curve of the source rock layers can be used in calculation.

\subsection{Relationship between the amount ( $\left.Q_{\text {expelled }}\right)$ of $\mathrm{HC}$ expelled from (unit mass of) source rocks and TOC as well as the lower limit of high-quality source rocks}

With the material balance principle of $Q_{\text {expelled }}=Q_{\text {generated }}{ }^{-}$ $Q_{\text {residual, }}$ it is easy to calculate the oil expelled from different source rocks in different sags but with the same TOC (and corresponding hydrocarbon generation potential) (Fig. 4). It can be seen from Fig. 4 that when TOC is low, the oil expulsion is really limited. This is because the oil generation is too small an amount to provide the residual amount in various forms (i.e. absorption, dissolution and hold by pores) in the source rocks. However, as TOC rises, the generated oil increases if other conditions (kerogen type and maturity) are almost unchanged, and a large amount of oil is expelled after enough oil remains in the source rocks in various forms (Pang, 1995). In other words, as the oil expulsion increases with TOC, there is an obvious inflection point on the curve. This shows that the relationship between the hydrocarbon expulsion of source rocks and their TOC is as the solid line shown in Fig. 2 at actual geological conditions. Namely highquality source rocks exist at geological conditions. Clearly, above the inflection point, the source rocks are of high quality, and the TOC corresponding to the point is the lower limit of high-quality source rocks. In this way, it is easy to calculate the lower limit of TOC $\left(\mathrm{TOC}^{0}\right)$ of different source rock layers in different sags, and this lower limit of TOC can be used for identifying high-quality source rocks (Table 1). It can be seen from Table 1 that the TOC lower limit of high-quality source rocks are different for different source rocks (corresponding to different geologic conditions), and ranges from 2.2 to 3.0. The reason will be discussed in the next section. It should be pointed out that $\mathrm{TOC}^{0}$ mentioned here refers to original organic carbon. Since there is not another inflection point on the $\mathrm{TOC}^{0}$-hydrocarbon expulsion curve, it seems unnecessary to create an identification standard of very high-quality source rocks among the high-quality source rocks.
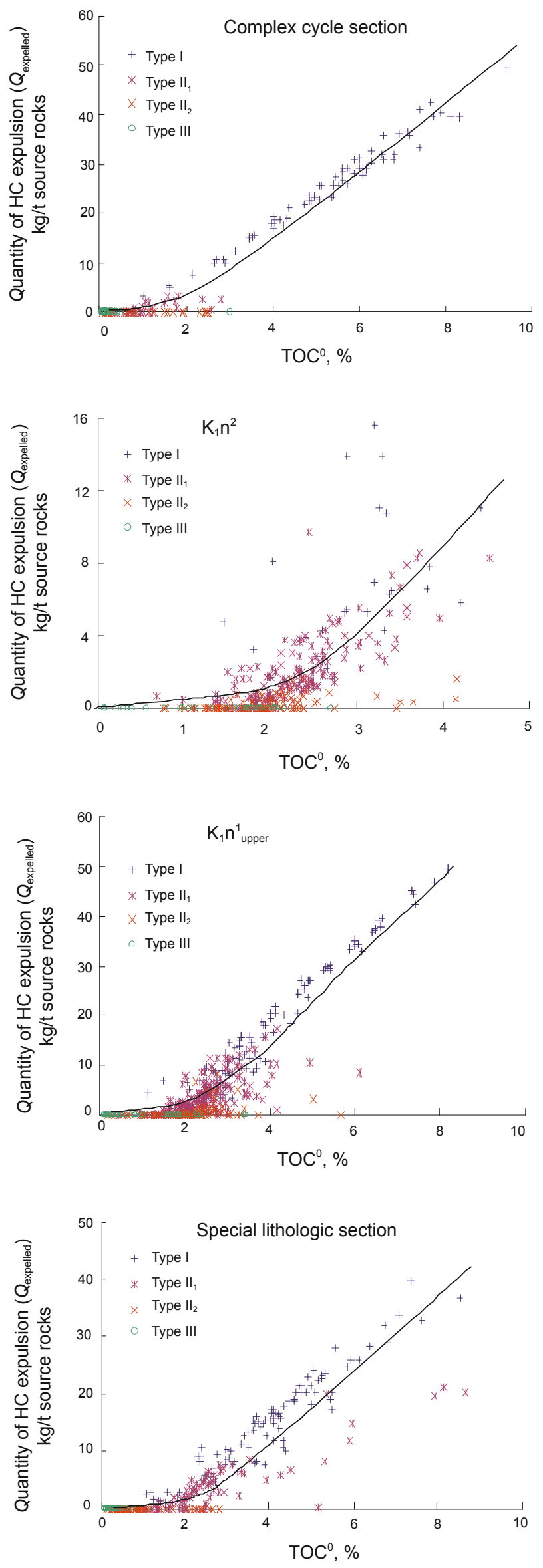

Fig. 4 Relationship of HC expulsion versus TOC in the Beier Sag (per unit mass of source rocks) 
Table 1 Lower limit of TOC of the source rocks in the Beier Sag

\begin{tabular}{ccc}
\hline \multirow{2}{*}{ Layer } & \multicolumn{2}{c}{ The lower limit of TOC, \% } \\
\cline { 2 - 3 } & Original TOC $^{0}$ & Residual TOC \\
\hline $\mathrm{K}_{1} \mathrm{n}^{2}$ & 2.70 & 2.15 \\
$\mathrm{~K}_{1} \mathrm{n}_{\text {upper }}^{1}$ & 3.00 & 2.37 \\
Special lithologic section & 2.20 & 1.63 \\
Complex cycle section & 2.30 & 1.73 \\
\hline
\end{tabular}

\subsection{Factors influencing the standard of high-quality source rocks and the lower limit of residual TOC}

\subsubsection{High-quality oil source rocks and high-quality gas source rocks}

As described above, the discussions in this paper mainly focus on oil source rocks. This is because that most of the source rocks in the target region have good kerogen types (Fig. 3), and their maturity is within the oil window range, furthermore the pools discovered in the basin are primarily oil reservoirs. In fact, the lower limit for identifying highquality gas source rocks can also be determined based on the principle of $Q_{\text {gas expelled }}=Q_{\text {gas generated }}-Q_{\text {residual gas }}$. But it is more difficult to determine the residual gas of the source rocks $\left(Q_{\text {residual gas }}=Q_{\text {absorbed gas }}+Q_{\text {dissolved gas }}+Q_{\text {gas remained in pores }}\right)$ than to determine the residual oil (which can be roughly determined with chloroform asphalt $\mathrm{A}$ or $\mathrm{S}_{1}$. Pang (1995) have already established an evaluation model $\left(Q_{\text {residual gas }}=Q_{\text {absorbed gas }}+Q_{\text {dissolved gas }}+Q_{\text {gas remained in pores }}\right)$, but there is still a lot of work to do to accurately obtain the relevant parameters. Currently, research on shale oil and gas is being conducted both in China and abroad, and it can lay a foundation for building more accurate residual gas model in the future. An evaluation standard for high-quality gas source rocks needs much more in-depth study.

\subsubsection{Influence of geologic conditions on the lower limit of} high-quality source rocks

As discussed above, the hydrocarbon expulsion generally increases as TOC rises, but only when reaches a threshold TOC value, the hydrocarbon expulsion may have an inflection point on the $Q_{\text {expelled }}$ versus TOC curve and grow significantly with increasing TOC, and the source rocks above the inflection point are of high quality. From the above discussion, the definition of high-quality source rocks can be given as the source rocks with TOC high enough to exceed the point when a large amount of hydrocarbon is expelled. High-quality source rocks are generally of high TOC, good kerogen type and moderate maturity (oil source rocks) or high maturity (gas source rocks). However, the lower limit of high-quality source rocks is different under different geologic conditions: Besides TOC all the geologic factors directly influencing the hydrocarbon generation and residuals and consequently influencing the hydrocarbon expulsion may affect the lower limit of high-quality source rocks, such as the type and maturity of organic matter. Generally, except for special geologic conditions favoring the generation of immature-low maturity oil ( $\mathrm{Lu}$ et al, 2001), immature-low maturity source rocks are unlikely to become high-quality source rocks. The closer to the oil generation peak (for oil source rocks) or the higher the maturity (for gas source rocks), the lower the TOC lower limit for high-quality source rocks; the better the kerogen type, the lower the TOC lower limit for high-quality source rocks. Actually, it can be observed in Fig. 4 that the oil expulsion of source rocks with type III and type $\mathrm{II}_{2}$ kerogen is always low, and it is impossible for such source rocks to be of high quality; in addition, the mineral components in source rocks can also impact the source rocks' ability to absorb and retain oil and gas (Pang, 1995), thus affecting the lower limit of high-quality source rocks.

\subsubsection{The lower limit of residual TOC of high-quality source rocks}

It should be noted that the lower limit of TOC mentioned above refers to the original $\mathrm{TOC}\left(\mathrm{TOC}^{0}\right)$ rather than the easily measured residual TOC. Obviously, it is not as convenient as the residual TOC in application. Therefore, the $\mathrm{TOC}^{0}$ should be converted into residual TOC. Fortunately, the residual TOC is easy to be calculated based on the present burial depth and thermal evolution history of the source rocks in every sag, and the results are shown in Table 1. The lower limit of residual TOC of the high-quality source rocks from different layers (corresponding to different geologic conditions) differs: it ranges from 1.63 to 2.37 , with an average value of about 2.0.

Strictly speaking, the evaluation standard for high-quality source rocks under different geologic conditions should be quantitatively determined using the above method, and the calculated lower limit will vary as the geologic conditions change. But this is rather complicated and not easy to apply. Taking the explorationists and geologists' habits into consideration, a simplified standard is recommended in this paper based on the above results: TOC $=2.0 \%$ can be the lower limit for evaluating high-quality oil source rocks. Since all types of kerogen (type I to III) are found in the source rocks in the study region, dominated by type $\mathrm{I}$ and type $\mathrm{II}_{1}$ (Fig. 3 ), and the maturity of the source rocks are within the oil window, so this standard should be applicable to evaluation of the oil source rocks within the oil window.

\section{Contribution of high-quality source rocks to hydrocarbon accumulation}

It is easy to build a model for calculating mudstone TOC from logging data, by the means of logging geochemical method, namely, using the correlation between the measured TOC and the resistivity as well as the correlation between the measured TOC and the acoustic time (Liu et al, 2011). In this way, the mudstone TOC of nearly 100 wells in the sag can be calculated from point to point. Then, the ordinary source rocks and high-quality source rocks in the region can be determined with $\mathrm{TOC}=2.0 \%$ as the lower limit to identify high-quality source rocks. Furthermore, the total mass of the ordinary and high-quality source rocks together with their respective oil generation and oil expulsion can be determined. The results are shown in Fig. 5 and Fig. 6 respectively. As 


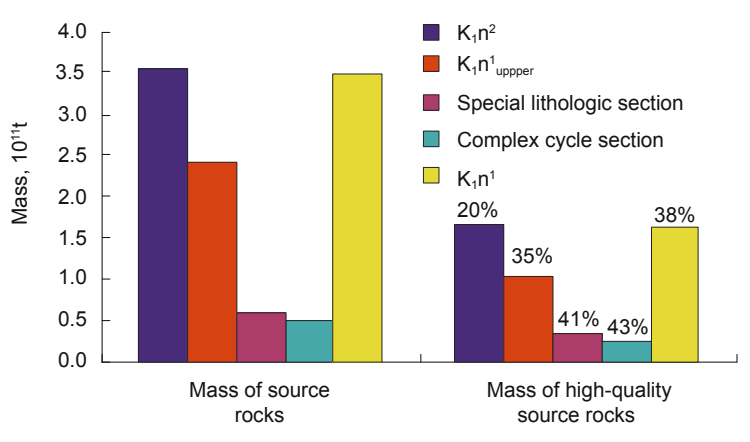

Fig. 5 Mass of source rocks and high-quality source rocks in the Beier Sag shown in the figures, the mass ratio of the high-quality source rocks in $\mathrm{K}_{1} \mathrm{n}^{2}$ and $\mathrm{K}_{1} \mathrm{n}^{1}$ (including the special lithologic section and the complex cycle section) is not high ( $46 \%$ on average), but their contributions to oil generation reach $76 \%$ and $82 \%$ respectively, and their contributions to oil expulsion are as high as $96 \%$ and $91 \%$ respectively. This indicates the huge contribution of high-quality source rocks to hydrocarbon accumulation. The distributions of $\mathrm{K}_{1} \mathrm{n}^{1}$ high-quality source rocks and oil reservoirs shows that the $\mathrm{K}_{1} \mathrm{n}^{1}$ high-quality source rocks have obvious source control effect on the oil pools (Fig. 7).

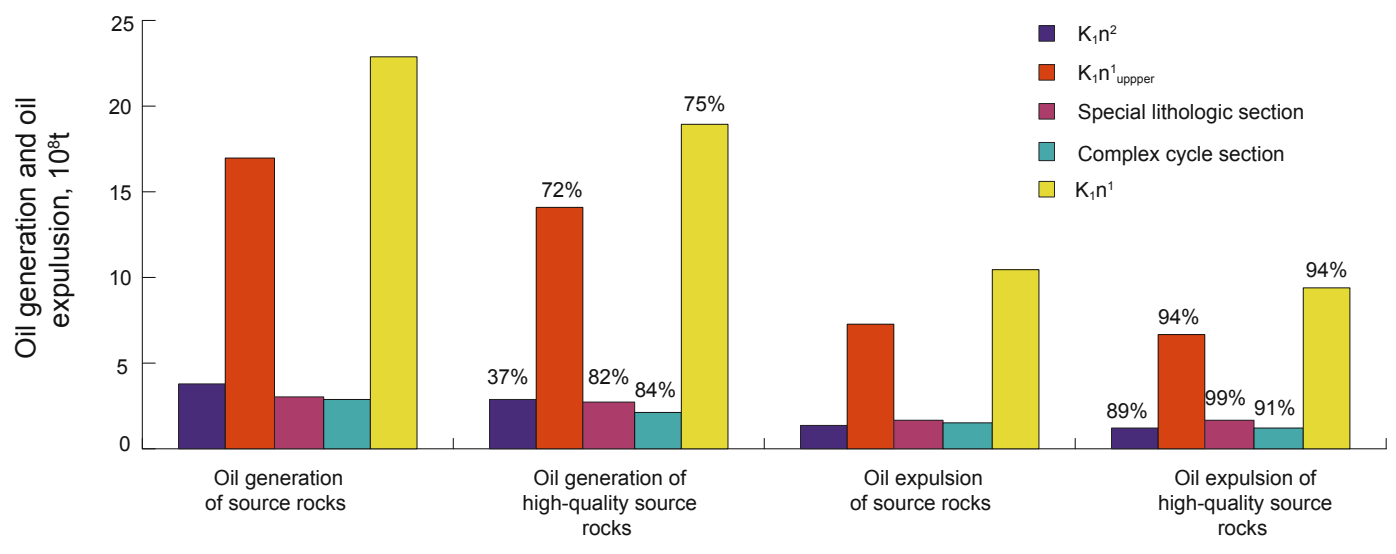

Fig. 6 Oil generation and oil expulsion of source rocks and high-quality source rocks in the Beier Sag

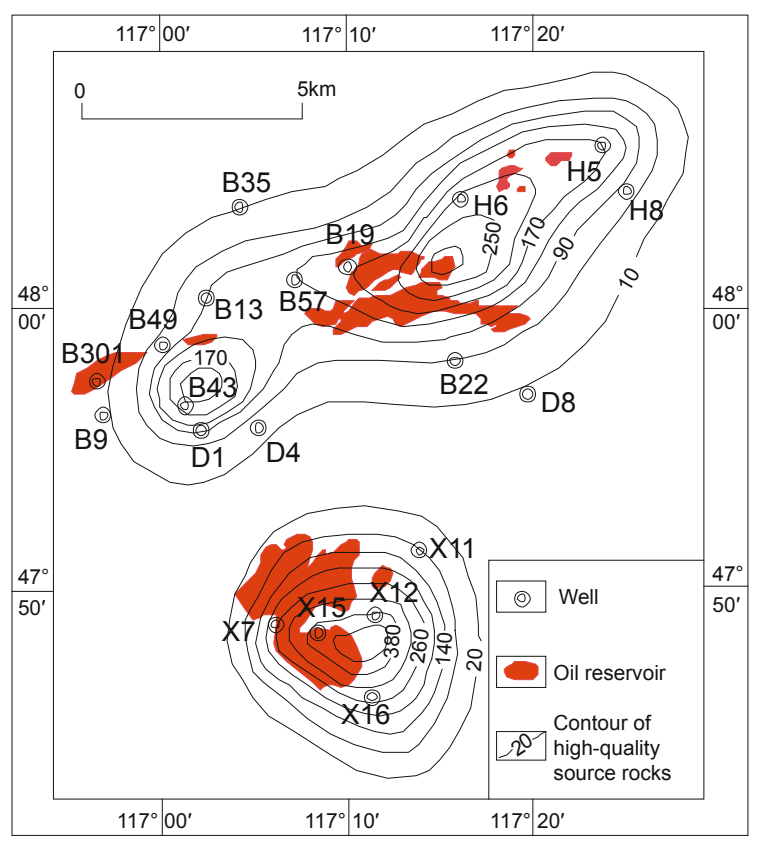

Fig. 7 Distributions of $\mathrm{K}_{1} \mathrm{n}^{1}$ high-quality source rocks and oil reservoirs in the Beier Sag

\section{Conclusions}

1) The lower limit of high-quality source rocks can be determined by using the inflection point on the hydrocarbon (oil) expulsion versus TOC curve of source rocks calculated based on the material balance principle, and the source rocks with a TOC higher than the inflection point value are highquality source rocks. In other words, high-quality source rocks can be defined as source rocks where the TOC is high enough to exceed the point when a large amount of hydrocarbon is expelled. They are generally the source rocks with high TOC, good kerogen type and moderate maturity (oil source rocks) or high maturity (gas source rocks).

2) Theoretically, the inflection point on the hydrocarbon expulsion versus TOC curve, or the lower limit of highquality source rocks, is related to the type and maturity of the organic matters in the source rocks as well as the mineral components of the source rocks affecting the residual hydrocarbons. Therefore, the lower limit of the high-quality source rocks depends on geological conditions rather than being constant. However, for the sake of simplicity and practicability, it is recommended that $\mathrm{TOC}=2.0 \%$ is regarded as the lower limit of high-quality source rocks.

3) The application of the standard in the work area indicates that the high-quality source rocks make more contribution to oil generation which is obviously higher than their weight proportion in total source rocks. Particularly, they control the oil expulsion. The distribution of hydrocarbon reservoirs in the region is also closely related to the distribution of high-quality source rocks, demonstrating that high-quality source rocks control hydrocarbon accumulation. 


\section{References}

Chen J F, Zhang S C, Sun S L, et al. Main factors influencing marine carbonate source rock formation. Acta Geologica Sinica. 2006. 80(3): 467-473 (in Chinese)

Fu J M, Sheng G Y, Xu J Y, et al. Application of biomarker compounds in assessment of paleoenvironments of Chinese terrestrial sediments. Geochimica. 1991. 1: 1-12 (in Chinese)

He F, Jin G X and Wei L H. Research on high quality source rock in the Dongpu Depression. Journal of Oil and Gas Technology. 2010. 32(4): 185-188 (in Chinese)

Hou D J, Zhang S W, Xiao J X, et al. The excellent source rocks and accumulation of stratigraphic and lithologic traps in the Jiyang depression, Bohai Bay Basin, China. Earth Science Frontiers. 2008. 15(2): 137-146 (in Chinese)

Jin Q. Importance and research about effective hydro-carbon source rock. Petroleum Geology and Recovery Efficiency. 2001. 8(1): 1-4 (in Chinese)

Jin Q, Zha M and Zhao L. Identification of effective source rocks in the Tertiary evaporate facies in the Western Qaidam Basin. Acta Sedimentologica Sinica. 2000. 18(1): 421-427 (in Chinese)

Jin Q, Zhu G Y and Wang J. Deposition and distribution of highpotential source rocks in saline lacustrine environments. Journal of China University of Petroleum (Edition of Natural Science). 2008. 32 (4): 19-24 (in Chinese)

Kong F X, Zhang L Y, Zhou W, et al. Geochemical characteristics and hydrocarbon-generating potential of good source rocks in the Jiyang Depression. Multiple Oil-Gas Field. 2000. 7(3): 13-15 (in Chinese)

Li C F and Xiao J F. The application of trace elements to the study of paleosalinities in the Shahejie Formation of the Dongying Basin, Shengli Oil Field. Acta Sedimentologica Sinica. 1988. 6(4): 100-107 (in Chinese)

Li R W, Lin D X, Wang Z Z, et al. The new criteria used for judging high-salinity environments. Chinese Science Bulletin. 1986. (8): 604607 (in Chinese)

Li T Y, He S and Yang Z. The marine source rock formation conditions and control factors. Geological Science and Technology Information. 2008. 27(6): 63-71 (in Chinese)

Liu C, Lu S F, Huang W B, et al. $\Delta \log$ technique: improvement and its application in source rocks evaluation. 2011. 30(3): 27-31(in Chinese)

Liu C L, Xu J L and Wang P X. Algal blooms: the primary mechanism in the formation of lacustrine petroleum source rocks. Geological Review. 2001. 47(2): 207-210 (in Chinese)

Liu X Y, Deng H W, Di Y X, et al. High quality source rocks of the Nantun formation in the Wuerxun Depression, the Hailaer Basin. Petroleum Geology \& Experiment. 2009. 31(1): 68-73 (in Chinese)

Lu S F. Kinetics Theory of Hydrocarbon Generation from Organic Matter and Its Application. Beijing: Petroleum Industry Press. 1996. 62-99 (in Chinese)

Lu S F, Fu G and Wang P Y. Quantitative Research into the Main Controlling Factors of Gas Accumulation. Beijing: Petroleum Industry Press. 2002. 106-178 (in Chinese)

Lu S F, Liu X Y, Fu X T, et al. Chemical kinetics study on the generation mechanism of immature to low-mature oil and its initial application. Acta Geologica Sinica. 2001. 19(1): 131-134 (in Chinese)

Lu S F, Liu X Y, Qu J Y, et al. Restoring original hydrocarbon potential and organic carbon of source rocks Huhehu Depression, Hailar Basin. Journal of Daqing Petroleum Institute. 1995. 19(1): 31-34 (in Chinese)

Lu S F, Li Z D, Li J J, et al. Chemical kinetic method of evaluating lowmaturity gas and its application in the Tuha Basin. Geochimica. 2009.
38(1): 68-74 (in Chinese)

Lu S F, Zhong N N, Xue H T, et al. Chemical kinetics study of hydrocarbon of regeneration from organic matter in carbonate source rocks and its significance. Science in China (Ser. D). 2007. 50(2): 536-543 (in Chinese)

Moldowan J M, Seifert W K, Gallegos E J. Relations between petroleum composition and depositional environment of petroleum source rocks. AAPG Bulletin. 1985. 69: 1255-1268

Pang X Q. Theory of Hydrocarbon Expulsion Threshold and Its Application. Beijing: Petroleum Industry Press. 1995. 8-108, 148245 (in Chinese)

Pang X Q, Guo Y H, Jiang F J, et al. High-quality source rocks and their distribution prediction in the Bohai Sea waters. Oil \& Gas Geology. 2009. 30(4): 393-398

Pedersen T F and Calvert S E. Anoxia vs. productivity: what controls the formation of organic carbon-rich sediments and sedimentary rocks. AAPG Bulletin. 1990. 74: 454-466

Qin J Z, Li Z M, Liu B Q, et al. The potential of generating heavy oil and solid bitumen in excellent marine source rocks. Petroleum Geology \& Experiment. 2007. 29(3): 280-285 (in Chinese)

Qin J Z, Tenger and Fu X D. Study of forming condition on marine excellent source rocks and its evaluation. Petroleum Geology \& Experiment. 2009. 31(4): 366-378 (in Chinese)

Tang X H. The Palaeogene supermicro fossil palaeoecology and haloenvironment in the Dongpu depression. Chinese Science Bulletin. 1986. (4): 298-300 (in Chinese)

Tenger, Gao C L, Hu K, et al. High-quality source rocks in the Lower Combination in Southeast Upper-Yangtze area and their hydrocarbon generating potential. Petroleum Geology \& Experiment. 2006. 28(4): 359-365 (in Chinese)

Tissot B P and Welte D. Petroleum Formation and Occurrence: A New Approach to Oil and Gas Exploration. Berlin: Springer-Verlag. 1978. 201-486

Wang J, Ma S P, Luo Q, et al. Recognition and resource potential of source rocks in the Raoyang Sag of the Bohai Bay Basin. Acta Petrolei Sinica. 2009a. 30(1): 51-56 (in Chinese)

Wang L, Jin Q, Lin L M, et al. Characteristics of quality Tertiary source rocks in the West Qaidam Basin. Natural Gas Industry. 2009b. 29(2): 23-26 (in Chinese)

Wang T G. A contribution to some sedimentary environmental biomarkers in crude oils and source rocks in China. Geochimica. 1990. 3: 256-262 (in Chinese)

Zhang L H, Kong X X, Zhang C R, et al. High quality oil prone source rocks in the Jiyang Depression. Geochimica. 2003. 32(1): 35-42 (in Chinese)

Zhang S C, Zhang B M, Wang F Y, et al. The two sets of effective source rock layers in the Talimu Basin - the type I organic matter characteristics, developing environment and controlling factors. Progress in Nature Science. 2001. 11(3): 261-268 (in Chinese)

Zheng H J, Dong Y X and Zhu G Y. High-quality source rocks in the Nanpu Sag. Petroleum Exploration and Development. 2007. 34(4): 385-342 (in Chinese)

Zhou J L. Prospect of logging evaluation of excellent hydrocarbon source rocks in offshore shelf basins in China. Marine Origin Petroleum Geology. 2009. 14(2): 52-59 (in Chinese)

Zhu G Y and Jin Q. Study on source rock heterogeneity - A case of Niu38 Well in the Dongying Depression. Acta Petrolei Sinica. 2002. 23(4): 34-39 (in Chinese)

Zhu G Y, Jin Q, Zhang S C, et al. Combination characteristics of lake facies source rock in the Shahejie formation, Dongying Depression. Acta Geologica Sinica. 2004. 78(3): 416-427 (in Chinese)

(Edited by Zhu Xiuqin) 